\title{
Ecosystem Spatial Changes and Driving Forces in the Bohai Coastal Zone
}

\author{
Min Cheng ${ }^{1,2}$, Binbin Huang ${ }^{1,2}$, Lingqiao Kong ${ }^{1,2}$ and Zhiyun Ouyang $1, * \mathbb{C}$ \\ 1 State Key Laboratory for Urban and Regional Ecological, Research Center for Eco-environmental Sciences, \\ Chinese Academy of Sciences, Haidian District, Beijing 100085, China; cmin611@163.com (M.C.); \\ 17190196351@163.com (B.H.); lqkong@rcees.ac.cn (L.K.) \\ 2 Research Center for Eco-environment Sciences, University of Chinese Academy Sciences, \\ Beijing 100049, China \\ * Correspondence: zyouyang@rcees.ac.cn; Tel.: +86-10-6284-9191
}

Received: 17 December 2018; Accepted: 11 February 2019; Published: 13 February 2019

check for updates

\begin{abstract}
Landscape change is an important aspect of coastal ecological conservation and has an essential influence on the sustainable development of the coastal economy. With remoting-sensing (RS) images between 2000, 2005, 2010, and 2015, using geographic information system (GIS) technologies, we examined ecosystem spatial changes in the Bohai coastal zone. Results showed that wetlands, mainly constituted by reservoirs/ponds, were the dominant landscape types. The urban ecosystem has the largest area increment and the fastest growth rate from 2000 to 2015 . The quantification of landscape metrics revealed that spatial patterns have changed significantly, and the change direction of these ecosystems had moved toward increased heterogeneity and fragmentation. In addition, natural and socio-economic data were used to analyze the major driving forces triggering ecosystem spatial changes through redundancy analysis (RDA). The results revealed that the output of aquatic products (AQ) and population (Pop) were the main factors related to wetland ecosystem change. Pop and gross domestic product per capita (GDPpc) were closely related to the urban ecosystem change. Annual mean temperature (ATm), crop acreage (CA), and grain yield (GY) had positive correlations with the agriculture ecosystem changes.
\end{abstract}

Keywords: ecosystem spatial changes; land use transition matrix; landscape metrics; driving forces

\section{Introduction}

Coastal zones are significant ecological boundaries, forming the transition area between terrestrial and marine ecosystems [1]. Coastal ecosystems provide easily accessible goods and services to humankind and play a significant role in coastal economic development and political interactions between countries [2]. One third of the world's population living within $100 \mathrm{~km}$ of a coast [3], and coastal communities are nearly three times more densely populated than inland areas [4]. The coastal region of China is comprised of an area of more than 3 million $\mathrm{km}^{2}$ and possesses an $18,000 \mathrm{~km}$ coastline stretching across tropical, subtropical, and temperate zones [5]. It is estimated that more than $70 \%$ of large Chinese cities are located in coastal zones, and coastal development plays a dominant role in the national economy. The value of coastal ecosystems accounts for more than $50 \%$ of its gross domestic product (GDP) [6]. The long-term sustainable development of coastal communities and the quality of human life closely depend on coastal ecosystems and the crucial services they generate, such as fishery production, climate mitigation, storm buffering and waste treatment [4]. The quality and quantity of ecosystem services are directly affected by coastal land cover/use change [7-9]. However, as the most densely populated area, Bohai coastal regions have experienced continuous alteration and transformation over the past decades, from 
wetland, forest and grassland to farmland and urban. These changes have negatively affected the ecosystem composition and structure, altered the production capacity and transformed the ecological attributes of the ecosystems, and influenced the nutritional transport between soil and vegetation [10]. Some natural coastal ecosystems are being continuously altered, transformed or destroyed which has resulted in the degraded function of ecosystem services, including ecosystem goods and services provision, environmental pollution control, biodiversity conservation, and human vulnerability to changing ecosystems [11,12]. Quantitative information on the historic change of landscape structure and composition was helpful for understanding the consequences of landscape changes $[13,14]$. Landscape pattern change analysis is increasingly considered an effective way for facilitating better policy decision-making in the sustainable development of coastal management. Landscape pattern change is usually quantified by landscape metrics [15-17]. Landscape pattern metrics are simple quantitative indices that concentrate landscape information and reflect the change characteristics of the ecosystem structure and spatial configuration. In recent decades, numerous researchers have focused on landscape status, landscape evolution, forecasting future landscape change, etc. [18-20]. Based on the reconstruction of historical landscape information, long-term human-environment interactions can be analyzed to develop a comprehensive understanding of these changes [21].

Driven by endogenous and exogenous factors in different spatial and temporal scales, the landscape is always in a state of dynamic change. Recent research has focused on the reasons behind the landscape changes and the "driving forces" have been developed into a fundamental concept [22], which is now used as a framework for identifying the causes, processes and consequences of landscape changes and has become indispensable for the assessment of policy decisions [23]. The definition of driving forces is the forces that cause observed landscape changes [24]. There are five major types of driving forces: socioeconomic, political, technological, natural and cultural driving forces [24]. These driving forces are not independent, and they influence the landscape change through non-linear interactions. The analysis on the driving forces of landscape change is a sort of directional research, and therefore there is no specific method or framework. However, statistical analysis is helpful to identify correlations between landscape changes and driving forces. Many studies analyzed the driving forces from the perspective of nature and socio-economic development $[25,26]$. The analysis of landscape spatial changes and its driving forces in different periods has become the latest trend. Although most current achievements have not explained fully the casual relationship and driving mechanism between factors and changes, they lay a good foundation for the further research in this field.

This study evaluated landscape changes of the coastal ecosystems in Bohai Bay from 2000 to 2015. With landscape pattern changes in Bohai Bay, especially the urban expansion and shrinkage of wetland ecosystems, certain ecological problems have emerged, such as wetland degradation and habitat loss and fragmentation. The quantitative analysis of landscape changes is necessary for the settlement of ecological problems resulting from landscape changes. The main goals of this study are: (1) to analyze the landscape changes of ecosystems in the Bohai coastal zone from 2000 to 2015 and (2) to identify the main driving forces of these changes during the past 15 years.

\section{Study Area}

The Bohai Sea is a "C"-shaped nearly enclosed sea. The scope of the coastal zone is a buffer zone, which is based on the coastline, and extends to a certain range across land and sea. There is no uniform standard for the division of the coastal zone at present, therefore, different researchers employ different definitions of coastal zones [27]. From the perspective of geomorphology, the coastal belt is a tideland zone between low and high tide. The widely accepted view is that the coastal zone is the area where the land interacts with the ocean. The coastal zone in this study is defined as the geographical area within the mainland with a distance of $10 \mathrm{~km}$ to the coastline, which is proposed as the basic unit in coastal zone evaluation. The coastal zone of the Bohai region spans three provinces and one municipality: Liaoning, Hebei, Shandong, and Tianjin, including 13 coastal cities: Dalian, Yingkou, 
Panjin, Jinzhou, Huludao, Qinhuangdao, Tangshan, Tianjin, Cangzhou, Binzhou, Dongying, Weifang, and Yantai from north to south, respectively (Figure 1).

Bohai bay plays an important role in national economic development. Administrations have proposed the conception of "Bohai Economic Rim" and distinctive development planning is implemented to boost coastal economy of Bohai bay. Driven by national policy, coastal landscapes are always under high development intensity and are being transformed at an unprecedent high rate in Bohai Bay. Coastal wetlands were reclaimed to meet the land needs for the construction of coastal ports, industrial parks, and coastal engineering projects. The construction scales of the Caofeidian industrial zone, Binhai new area of Tianjin, Huanghua port, and Dongying port have been gradually expanding since the implementation of the tenth "five-year plan," inevitably changing the coastal ecosystem structure and spatial configuration.

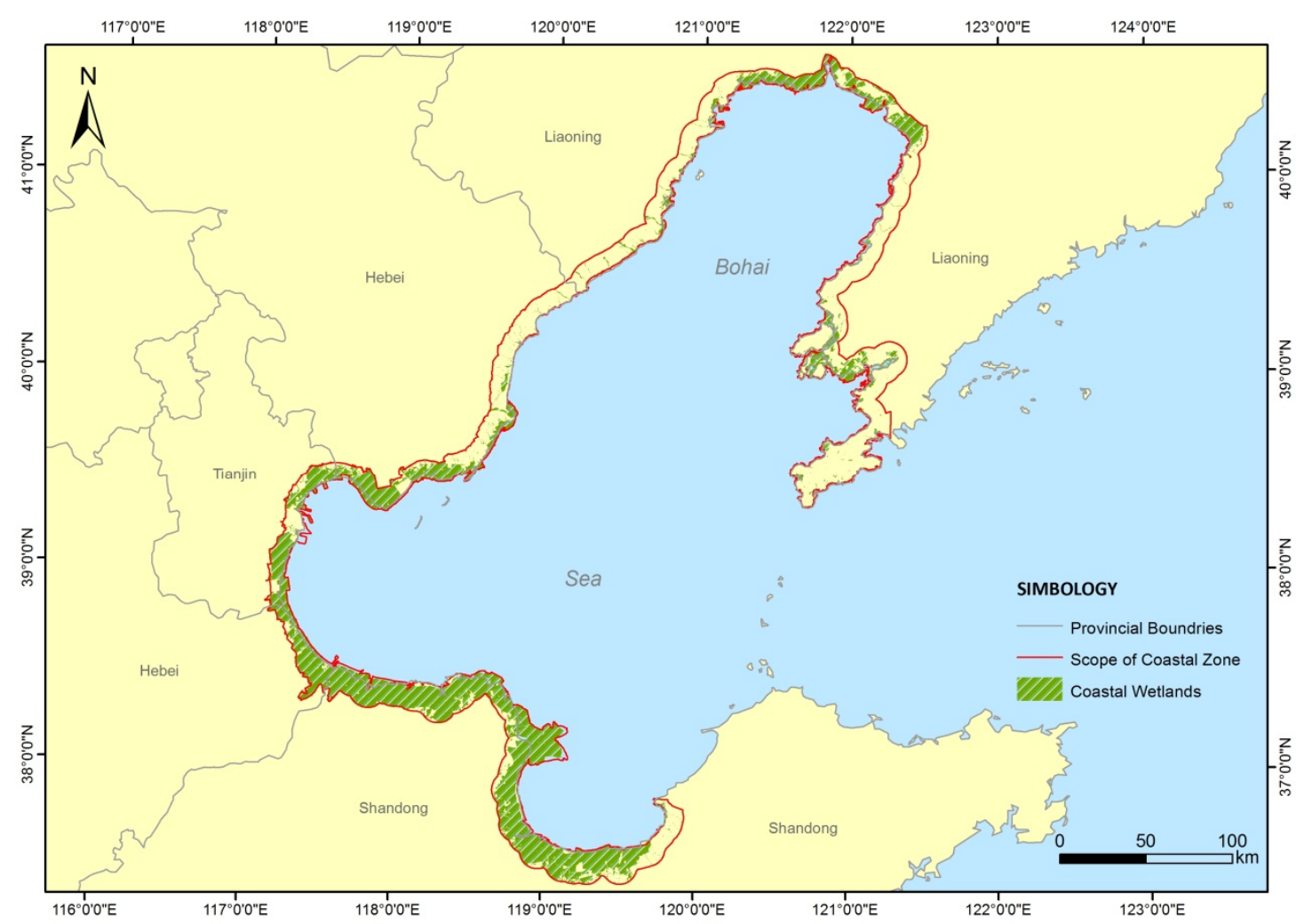

Figure 1. Location of the study area in China.

\section{Data and Methods}

\subsection{Data}

Based on geographic information system (GIS) (ArcGIS 10.3) (ESRI, Redlands, CA, USA) technology, we have processed Landsat Thematic Mapper (TM) remote-sensing images of four typical periods in 2000, 2005, 2010 and 2015. The main data sources are Landsat TM images with $30 \mathrm{~m}$ spatial resolution during June to October. The ecosystem classification data came from the project "Survey and Assessment of National Ecosystem Changes between 2000 and 2010," supported by the Ministry of Environmental Protection (MEP) of China and Chinese Academy of Sciences (CAS) [28], and the project "Survey and Assessment of National Ecosystem Changes between 2010 and 2015." The research region is divided into seven categories: forest ecosystem (FE), shrub ecosystem (SE), grassland ecosystem (GL), wetland ecosystem (WE), farmland ecosystem (FL), urban ecosystem (UE), and bare land (BL). These ecosystems were subdivided into 24 classes. 


\subsection{Methods}

\subsubsection{Landscape Changes}

Changes in area, landscape dynamic degree, landscape change index, and the transition matrix of landscape types are four main indicators to depict landscape dynamics.

To quantitatively depict the range and speed of the ecosystems, the dynamic degree $(K)$ was adopted and calculated. $K$ refers to the percentage of ecosystem area changes per year within the initial ecosystem area, which can quantitatively reveal the ecosystem area change rate. The equation to calculate $K$ is as follows [25,29]:

$$
K=\frac{A_{t+1}-A_{t}}{A_{t}} \times \frac{1}{\Delta t} \times 100 \%
$$

$K$ refers to the dynamic degree of land use for a specific ecosystem, defined as the percent of land use change per year, and $A_{t}$ and $A_{t+1}$ represent the area of the coastal landscape for times $t$ and $t+1$, $\Delta t$ means the duration of a certain period.

The landscape change index (LCI) is a good index to depict the overall landscape changes. The definition of the LCI is the absolute values of change in ecosystem types that have greatest impact on the formation of the landscape [30]. The LCI was calculated for each time interval by multiplying a factor of one-half by the sum of the absolute values of change in area proportion of each ecosystem type in relation to the total analyzed area, a constant of one-half was adopted to reflect the actual change level because summing the absolute values of change of each ecosystem type essentially doubled the index. The Equation for calculating LCI is:

$$
L C I_{t i}=\frac{1}{2} \times \sum_{i=1}^{n}\left|C A_{i}\right|
$$

where $L C I_{t i}$ represents the landscape change index in each time interval; $\left|C A_{i}\right|$ represents the absolute value of change in area proportion of each ecosystem type in relation to the total analyzed area, it was calculated with the following equation:

$$
C A_{i}=\left(S_{t+1} / S_{t}\right) / T A
$$

where $C A_{i}$ represents the changes in area proportion of each ecosystem type in relation to the total area of research (\%), $S_{t+1}$ and $S_{t}$ represents the area of each ecosystem type during the time interval $t+1$ $\left(\mathrm{km}^{2}\right)$ and $t\left(\mathrm{~km}^{2}\right)$; TA represents the total research area $\left(\mathrm{km}^{2}\right)$.

The cross-tabulation matrix method [31] was used to analyze the landscape changes in three-time intervals $(2000-2005,2005-2010,2010-2015)$. Table 1 showed the format of transition matrix. The columns display the categories of time 1 and the rows display the categories of time $2 ; P_{i j}$ represents the proportion of the landscape that experiences a transition from category $i$ to $j ; P_{i i}$ represents the proportion of the landscape that shows persistence of category $i ; P_{i+}$ and $P_{+j}$ represent the proportion of the landscape in category $i$ in time 2 and category $j$ in time 1 respectively. The column of gain and net change indicate the proportion of landscape that experiences gross gain and net change of each

\begin{tabular}{|c|c|c|c|c|c|c|c|}
\hline $\begin{array}{ll}\text { Time } 2 & \text { Time } 1 \\
\end{array}$ & Category 1 & Category 2 & Category 3 & Category 4 & Total Time 2 & Gain & Net Change \\
\hline Category 1 & $P_{11}$ & $P_{21}$ & $P_{31}$ & $P_{41}$ & $P_{+1}$ & $P_{+1}-P_{11}$ & $P_{+1}-P_{1+}$ \\
\hline Category 2 & $P_{12}$ & $P_{22}$ & $P_{32}$ & $P_{42}$ & $P_{+2}$ & $P_{+2}-P_{22}$ & $P_{+2}-P_{2+}$ \\
\hline Category 3 & $P_{13}$ & $P_{23}$ & $P_{33}$ & $P_{43}$ & $P_{+3}$ & $P_{+3}-P_{33}$ & $P_{+3}-P_{3+}$ \\
\hline Category 4 & $P_{14}$ & $P_{24}$ & $P_{34}$ & $P_{44}$ & $P_{+4}$ & $P_{+4}-P_{44}$ & $P_{+4}-P_{4+}$ \\
\hline $\begin{array}{l}\text { Total time } 1 \\
\text { Loss }\end{array}$ & $\begin{array}{c}P_{1+} \\
P_{1+}-P_{11}\end{array}$ & $\begin{array}{c}P_{2+} \\
P_{2+}-P_{22}\end{array}$ & $\begin{array}{c}P_{3+} \\
P_{3+}-P_{33}\end{array}$ & $\begin{array}{c}P_{4+} \\
P_{4++}-P_{44}\end{array}$ & 1 & & \\
\hline
\end{tabular}
landscape type between time 1 and 2 .

Table 1. Transition matrix for comparing landscape changes in time [31]. 


\subsubsection{Landscape Metrics}

The spatial configuration of coastal landscapes is as much a reflection of the past as it is an indicator of the current socioeconomic processes and interactions [32]. Commonly, landscape metrics can be used to conduct empirical analysis of landscape pattern changes. A wide variety of metrics for characterizing landscapes have been proposed [33]. In view of numerous landscape metrics, we chose appropriate metrics based on four criteria: (1) comparability with previous research on landscape pattern changes; (2) ability to indicate ecological conditions of ecosystems; (3) low redundancy among landscape indices; and 4) ability to reflect the landscape pattern characteristics within the study area [34]. Based on the objectives of this paper and the general situation of the study area, four metrics at class level (NP, PD, MPS, and LPI) and five metrics at landscape level (NP, PD, MPS, LPI, and SHDI) were chosen to illustrate landscape pattern changes. Fragstats 4.2.1, developed by the Forest Science Department, Orgen State University, USA, is a program for quantifying landscape metrics for each period and analyzing the ecosystem spatial changes of the Bohai coastal region [35]. The definition and description of the landscape metrics are given in the Fragstats user's guide [35]. The formulas [35] are as follows:

1. NP: Number of patches NP $=n_{i} ; n$ : the number of patches, $\mathrm{NP} \geq 1$, without limit.

2. PD: Patch density $\mathrm{PD}=N / A ; N$ : number of patches; $A$ : total landscape area, $\mathrm{PD}>0$, without limit.

3. MPS: Mean patch size MPS $=A / N ; N$ : number of patches; $A$ : total landscape area, MPS $>0$, without limit.

4. LPI: Largest patch index LPI $=\operatorname{Max}\left(a_{1}, \ldots a_{n}\right) / A \times 100 ; a_{i}$ : area of patch $i ; A$ : total landscape area, $0<$ LPI $\leq 100$.

5. SHDI: Shannon-Weaver diversity index SHDI $=-\sum_{i=1}^{m}\left[P_{i} \ln \left(P_{i}\right)\right] ; P_{i}:$ the proportion of landscape occupied by patch type $i$; $m$ : number of patch types present in the landscape. SHDI $\geq 0$.

\subsubsection{Driving Forces Analysis}

Ordination is a widely used method which attempts to reveal the relationships between ecological landscapes and environmental variables [36]. Detrended correspondence analysis (DCA) was firstly performed to test the length of environmental gradients of the axes. The length of environmental gradient is 0.67 , thus redundancy analysis (RDA) was used to analyze the relationships between landscape changes and environmental variables.

The relative socio-economic data in this study mostly came from the public statistical yearbook of history (2015). The driving force of ecosystem pattern change in the Bohai coastal zone includes seven factors: annual mean precipitation $(\mathrm{APm}, \mathrm{mm})$, annual mean temperature $\left(\mathrm{ATm},{ }^{\circ} \mathrm{C}\right)$, population (Pop, person), GDP per capita (GDPpc, yuan/per capita), crop acreage (CA, $10^{3} \mathrm{hm}^{2}$ ), grain yield (GY, $10^{4}$ tons), and output of aquatic products (AQ, $10^{4}$ tons). In consideration of different dimensions of driving factors, the deviation normalization method was adopted to preprocess the data. Then DCA and RDA were performed with Canoco 4.5 (Microcomputer Power, Ithaca, NY, USA) for Windows.

\section{Results}

\subsection{Characteristics of Ecosystem Spatial Changes}

\subsubsection{Spatial Distribution Characteristics of Ecosystems}

Many ecosystems constitute the complex landscape pattern of the Bohai coastal zone. The total area and proportions of different ecosystems were shown in Table 2 and Figures 2 and 3. 


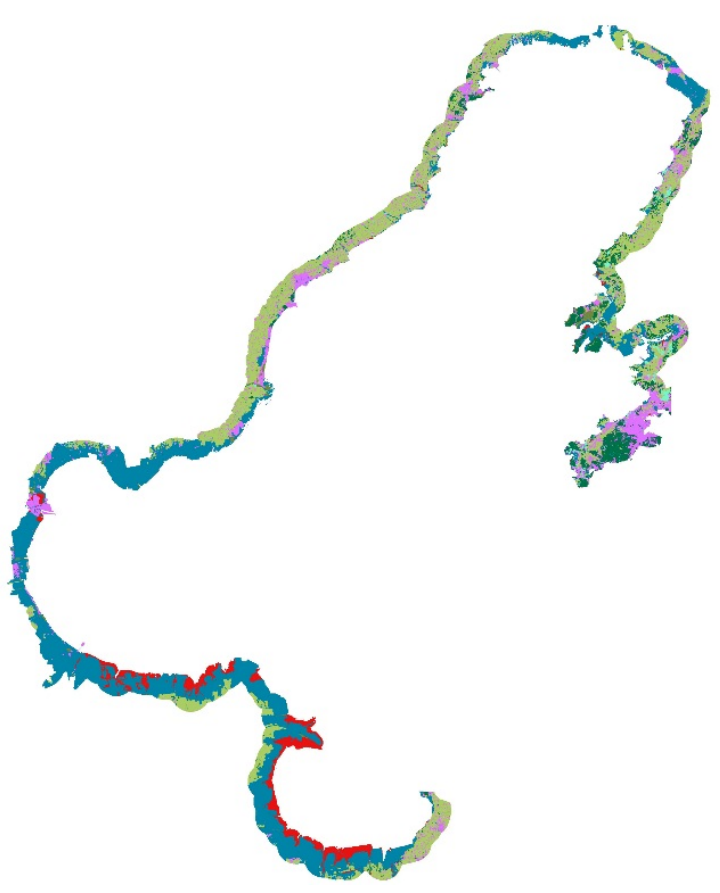

(a) 2000

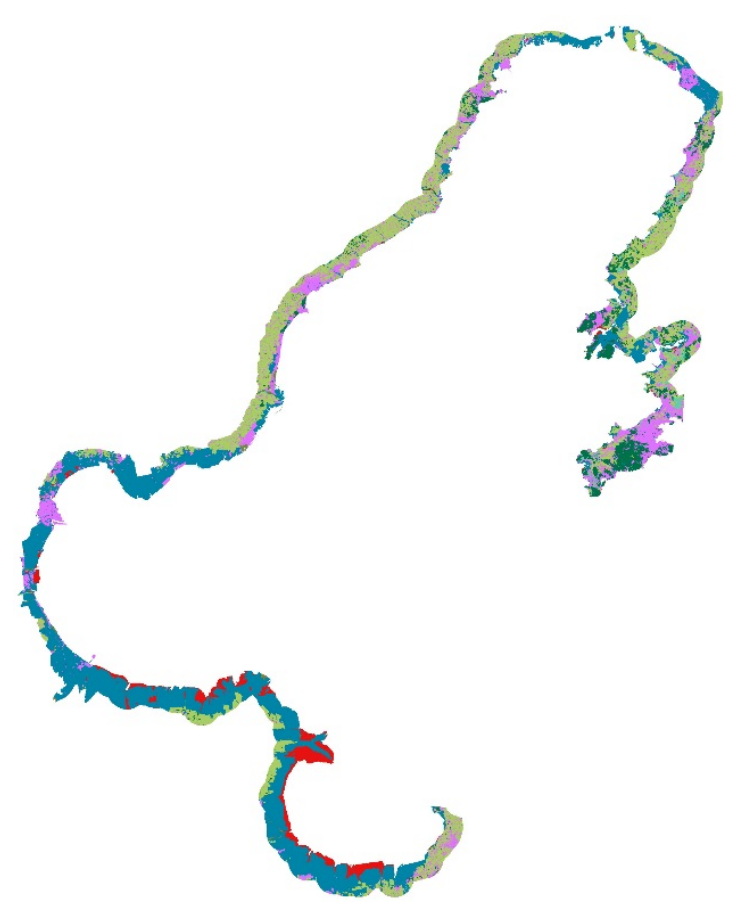

(c) 2010

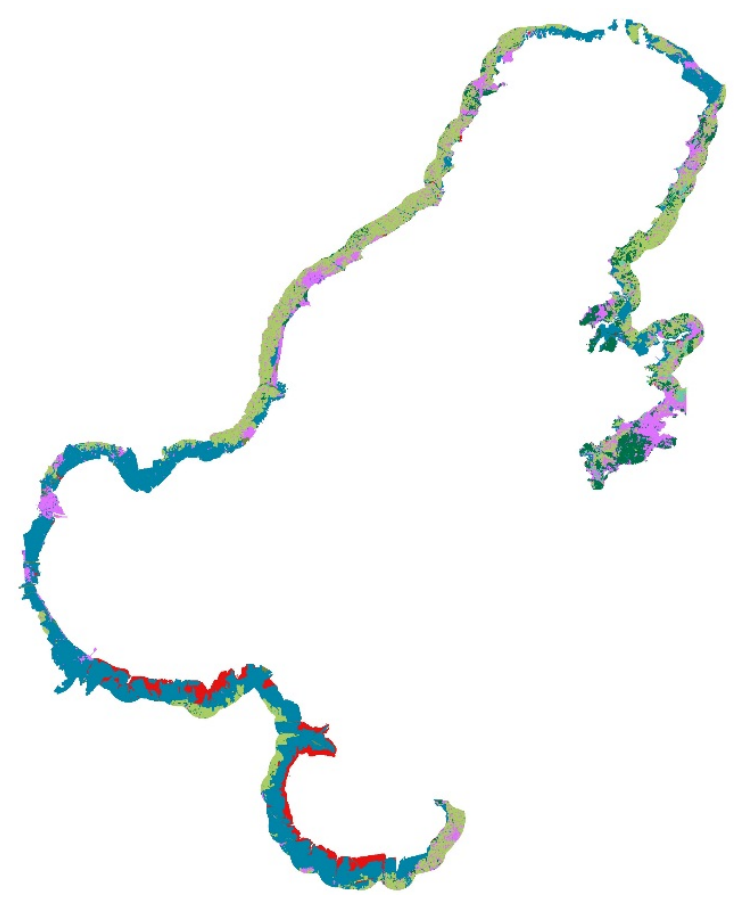

(b) 2005

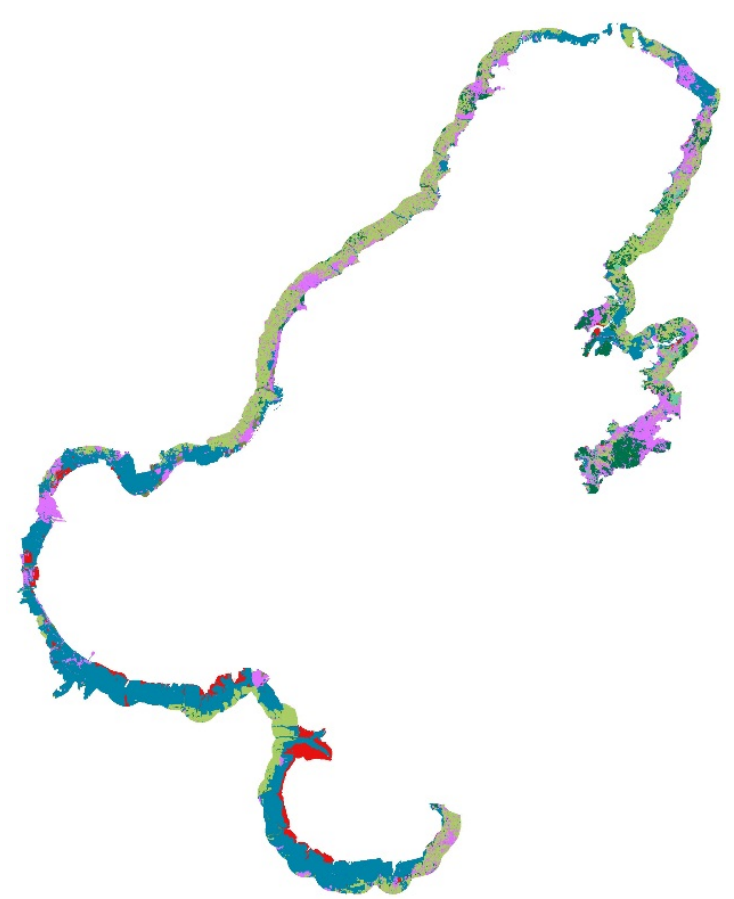

(d) 2015

Figure 2. Cont. 


\section{Ecosystem types}
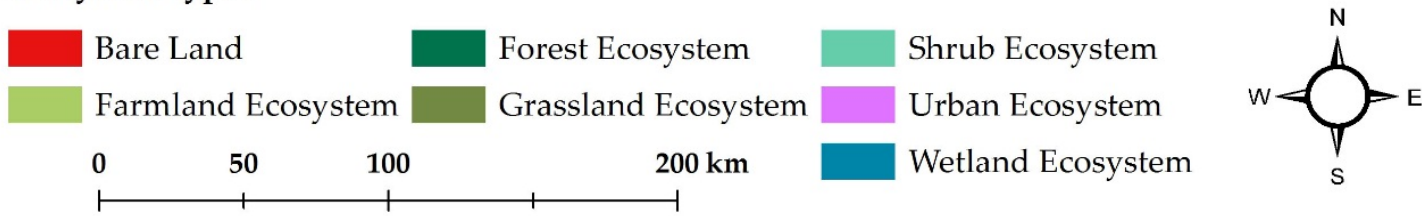

Figure 2. Landscape changes of Bohai coastal zone between 2000 and 2015: (a) map of ecosystems in 2000; (b) map of ecosystems in 2005; (c) map of ecosystems in 2010; (d) map of ecosystems in 2015.

From 2000 to 2015, the wetland ecosystem had the largest area, accounting for about 39\% of the total area, followed by farmland, urban ecosystem, and forest ecosystem. The area of these four ecosystems accounts for $90 \%$ of the total coastal zone (Figure 3).

Reservoir/pond was the main landscape type of the wetland ecosystem, accounting for $84.53 \%$ of the total wetland area; dry land was the predominant landscape type of the farmland ecosystem, accounting for $90.44 \%$ of the total farmland area; residential land accounted for $92.02 \%$ of the total urban area and was the dominant urban ecosystem type; broad-leaved forest has the largest area, accounting for $86.64 \%$ of the total forest area (Table 2).

Table 2. Area and proportion of ecosystems from 2000 to 2015.

\begin{tabular}{|c|c|c|c|c|c|c|c|c|c|}
\hline & \multirow{2}{*}{ Ecosystem Types } & \multicolumn{2}{|c|}{2000} & \multicolumn{2}{|c|}{2005} & \multicolumn{2}{|c|}{2010} & \multicolumn{2}{|c|}{2015} \\
\hline & & $\begin{array}{c}\text { Area } \\
\left(\mathbf{k m}^{2}\right)\end{array}$ & $\begin{array}{l}\text { Proportion } \\
(\%)\end{array}$ & $\begin{array}{c}\text { Area } \\
\left(\mathbf{k m}^{2}\right)\end{array}$ & $\begin{array}{l}\text { Proportion } \\
\text { (\%) }\end{array}$ & $\begin{array}{c}\text { Area } \\
\left(\mathrm{km}^{2}\right)\end{array}$ & $\begin{array}{l}\text { Proportion } \\
\text { (\%) }\end{array}$ & $\begin{array}{c}\text { Area } \\
\left(\mathbf{k m}^{2}\right)\end{array}$ & $\begin{array}{l}\text { Proportion } \\
(\%)\end{array}$ \\
\hline \multirow{4}{*}{$\mathrm{WE}^{1}$} & Marsh land & 1113.5 & 7.5 & 1022.0 & 6.9 & 804.1 & 5.4 & 599.6 & 4.0 \\
\hline & Lake & 7.0 & 0.0 & 8.1 & 0.1 & 5.0 & 0.0 & 5.1 & 0.0 \\
\hline & Reservoir/Pond & 4515.9 & 30.5 & 4640.3 & 31.3 & 4757.7 & 32.1 & 4653.8 & 31.4 \\
\hline & River & 208.2 & 1.4 & 213.4 & 1.4 & 233.5 & 1.6 & 247.2 & 1.7 \\
\hline \multirow{3}{*}{$\mathrm{FL}^{2}$} & Paddy field & 409.6 & 2.8 & 348.6 & 2.4 & 363.2 & 2.4 & 378.1 & 2.6 \\
\hline & Dry land & 4206.1 & 28.4 & 4054.3 & 27.3 & 3904.3 & 26.3 & 3966.9 & 26.8 \\
\hline & Garden plot & 36.1 & 0.2 & 40.7 & 0.3 & 41.9 & 0.3 & 41.4 & 0.3 \\
\hline \multirow{5}{*}{$\mathrm{UE}^{3}$} & Residential land & 1520.0 & 10.3 & 1717.8 & 11.6 & 2270.0 & 15.3 & 2549.9 & 17.2 \\
\hline & Urban green land & 75.6 & 0.5 & 78.7 & 0.5 & 82.1 & 0.6 & 88.7 & 0.6 \\
\hline & Transportation land & 73.7 & 0.5 & 89.1 & 0.6 & 104.3 & 0.7 & 118.6 & 0.8 \\
\hline & Mining area & 9.0 & 0.1 & 10.4 & 0.1 & 9.3 & 0.1 & 13.8 & 0.1 \\
\hline & Industrial land & 198.5 & 1.3 & 290.5 & 2.0 & 0.0 & 0.0 & 0.0 & 0.0 \\
\hline \multirow{4}{*}{$\mathrm{FE}^{4}$} & Broad-leaved forest & 1006.5 & 6.8 & 1029.1 & 6.9 & 1038.9 & 7.0 & 1026.0 & 6.9 \\
\hline & Coniferous forest & 66.2 & 0.4 & 71.6 & 0.5 & 68.9 & 0.5 & 70.3 & 0.5 \\
\hline & $\begin{array}{l}\text { Mixed broadleaf-conifer } \\
\text { forest }\end{array}$ & 85.9 & 0.6 & 89.0 & 0.6 & 89.6 & 0.6 & 87.4 & 0.6 \\
\hline & Sparse forest & 0.0 & 0.0 & 0.0 & 0.0 & 0.0 & 0.0 & 0.5 & 0.0 \\
\hline $\mathrm{BL}^{5}$ & Bare land & 925.7 & 6.2 & 814.4 & 5.5 & 749.5 & 5.1 & 646.4 & 4.4 \\
\hline \multirow{3}{*}{$\mathrm{SE}^{6}$} & Broadleaf shrub & 206.4 & 1.4 & 214.5 & 1.4 & 215.3 & 1.5 & 208.2 & 1.4 \\
\hline & Acerola shrub & 0.1 & 0.0 & 0.1 & 0.0 & 0.2 & 0.0 & 0.2 & 0.0 \\
\hline & Sparse shrub & 0.0 & 0.0 & 0.0 & 0.0 & 0.0 & 0.0 & 0.5 & 0.0 \\
\hline \multirow{4}{*}{$\mathrm{GL}^{7}$} & Meadow & 0.0 & 0.0 & 0.0 & 0.0 & 1.5 & 0.0 & 0.2 & 0.0 \\
\hline & Prairie & 77.2 & 0.5 & 7.9 & 0.1 & 0.0 & 0.0 & 0.6 & 0.0 \\
\hline & Tussock & 44.3 & 0.3 & 58.4 & 0.4 & 55.2 & 0.4 & 49.0 & 0.3 \\
\hline & Sparse grassland & 43.6 & 0.3 & 29.0 & 0.2 & 31.4 & 0.2 & 73.2 & 0.5 \\
\hline
\end{tabular}

${ }^{1}$ Wetland ecosystems; ${ }^{2}$ farmland ecosystems; ${ }^{3}$ urban ecosystems; ${ }^{4}$ forest ecosystems; ${ }^{5}$ bare land; ${ }^{6}$ shrub ecosystems; ${ }^{7}$ grassland ecosystems. 


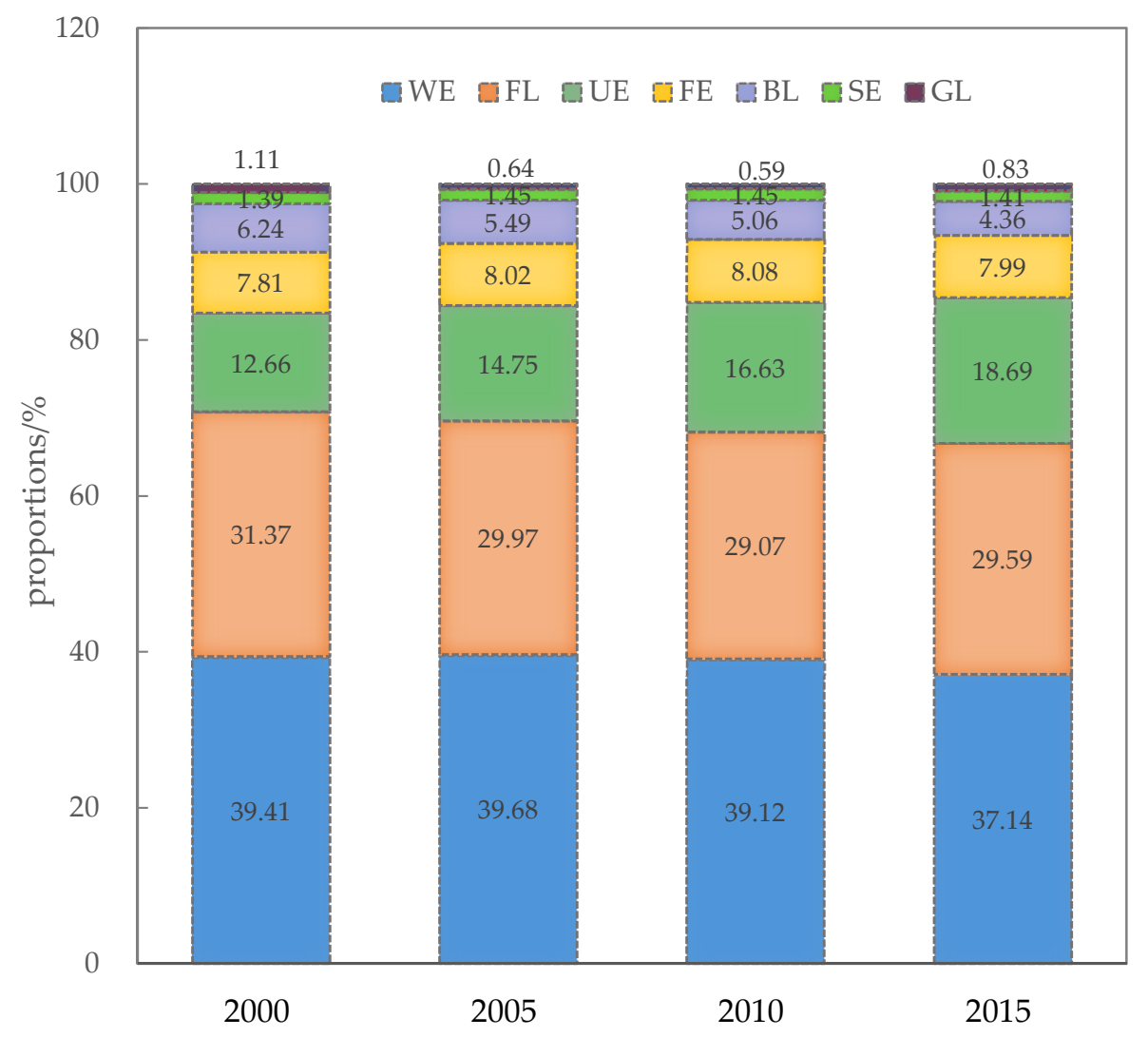

Figure 3. Proportions of different ecosystems in 2000, 2005, 2010 and 2015.

\subsubsection{Characteristics of Ecosystem Spatial Changes}

The statistics show that the areas of the observed ecosystems have all changed from 2000 to 2015 (Figure 4). Significant changes mainly occurred in urban, farmland, wetland and bare land ecosystems. The trend of landscape changes is characterized by the expansion of urban and the shrinkage of farmland, wetland and bare land. The urban ecosystems exhibited the largest area increment in these three time intervals. The largest decrease occurred in farmland ecosystems during 2000-2005 and 2005-2010. The area of wetland ecosystems showed the largest decrease during 2010-2015. The area of bare land continuously decreased from 2000-2015.

The dynamic degree $(K)$ of all ecosystem types in the study area were calculated using Equation (1) (Table 3). During 2000-2005, the $K$ value of grassland ecosystems was the largest, accounting for $-8.46 \%$ of the change in total landscape, which indicated that the change amplitude of grassland was the biggest, followed by those of urban and bare land, accounting for $3.3 \%$ and $-2.4 \%$ of the change in total landscape, respectively. From 2005 to 2010, the K value of urban ecosystems was the highest, accounting for $2.56 \%$ of the change in total landscape, followed by bare land and grassland, accounting for $-1.59 \%$ and $-1.51 \%$ of the change in total landscape. In the period $2010-2015$, the $K$ value of grassland ecosystems was the largest, accounting for $7.93 \%$ of the change in total landscape, followed by urban and bare land; the change of other ecosystems was comparatively small.

The landscape change index level (LCI) in the period 2000-2005 and 2010-2015 was relatively higher than the index for the period 2005-2010 (Table 3), indicating that the largest changes of the landscape occurred in the first and the third time interval. 


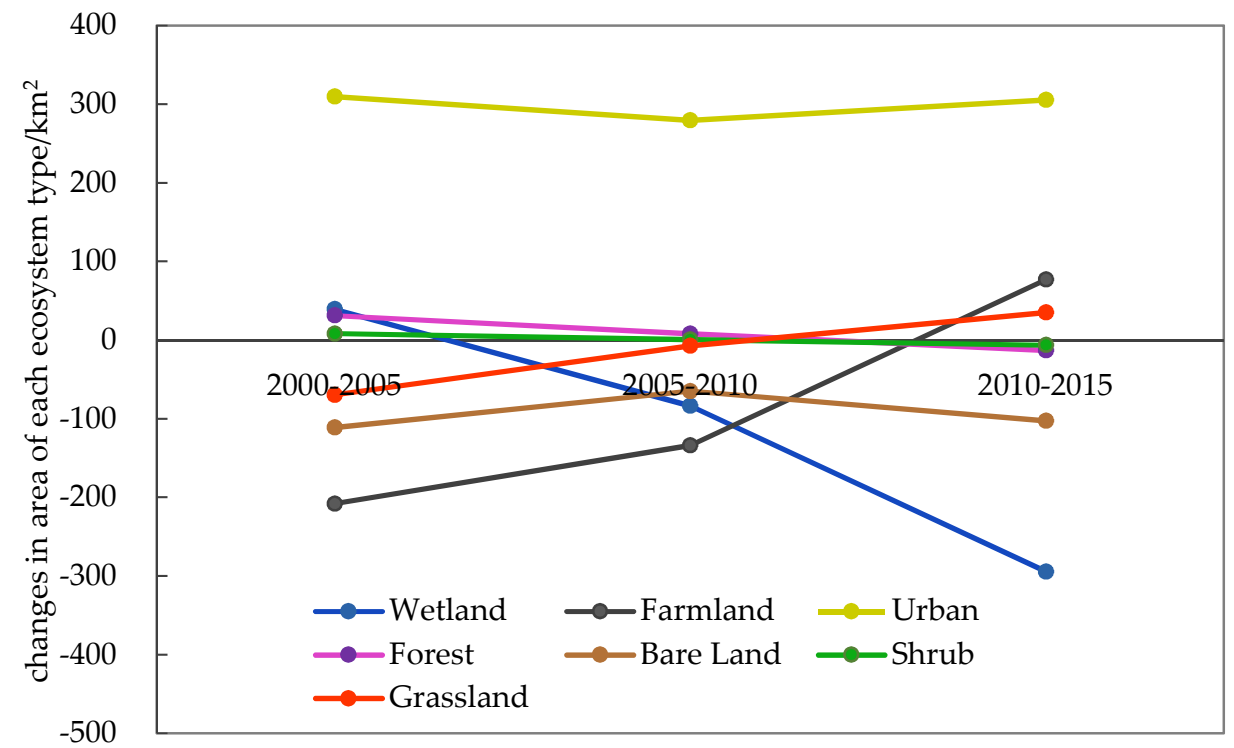

Figure 4. Area changes of ecosystems from 2000 to 2015.

Table 3. Dynamics of landscape changes in ecosystems in the research area during 2000-2015.

\begin{tabular}{ccccccccc}
\hline \multirow{2}{*}{ Time Interval } & \multirow{2}{*}{ Indicator } & \multicolumn{7}{c}{ Ecosystem Types } \\
\cline { 3 - 9 } & & $\mathbf{W E}^{\mathbf{1}}$ & FL $^{\mathbf{2}}$ & $\mathbf{U E}^{\mathbf{3}}$ & $\mathbf{F E}^{\mathbf{4}}$ & $\mathbf{B L}^{\mathbf{5}}$ & SE $^{\mathbf{6}}$ & $\mathbf{G L}^{\mathbf{7}}$ \\
\hline \multirow{3}{*}{$2000-2005$} & $\mathrm{~K} / \%$ & +0.13 & -0.89 & +3.30 & +0.54 & -2.40 & +0.79 & -8.46 \\
& $\mathrm{CA} / \%$ & 0.26 & -1.40 & 2.09 & 0.21 & -0.75 & 0.05 & -0.47 \\
& $\mathrm{LCI}$ & & & & 2.62 & & & \\
\hline \multirow{3}{*}{$2005-2010$} & $\mathrm{~K} / \%$ & -0.28 & -0.60 & +2.56 & +0.13 & -1.59 & 0.08 & -1.51 \\
& $\mathrm{CA} / \%$ & -0.56 & -0.91 & 1.88 & 0.05 & -0.44 & 0.01 & -0.05 \\
& $\mathrm{LCI}$ & & & & 1.95 & & & \\
\hline \multirow{2}{*}{$2010-2015$} & $\mathrm{~K} / \%$ & -1.02 & +0.36 & +2.48 & -0.22 & -2.75 & -0.61 & +7.93 \\
& $\mathrm{CA} / \%$ & -1.99 & 0.52 & 2.06 & -0.09 & -0.69 & -0.04 & 0.24 \\
& $\mathrm{LCI}$ & & & & 2.81 & & & \\
\hline
\end{tabular}

${ }^{1}$ Wetland ecosystems; ${ }^{2}$ farmland ecosystems; ${ }^{3}$ urban ecosystems; ${ }^{4}$ forest ecosystems; ${ }^{5}$ bare land; ${ }^{6}$ shrub ecosystems; ${ }^{7}$ grassland ecosystems; " $K$ " indicates the increase; " $-K$ " indicates the decrease.

In the period 2000-2005, farmland (FL) showed the largest loss, $2.24 \%$ of the entire coastal zone, and urban (UE) showed the largest gain, $2.64 \%$ of the coastal zone (Table 4 ). Most of the lost farmland converted into urban (UE). From 2000-2005, the largest net loss is farmland (FL) (-1.4\%), and the largest net gain is urban (UE) $(2.09 \%)$. The main contributor for the increment of urban was farmland $(1.28 \%)$ and wetland $(0.71 \%)$.

Table 4. Landscape transition matrix between 2000 (columns) and 2005 (rows).

\begin{tabular}{|c|c|c|c|c|c|c|c|c|c|c|}
\hline $2005-2000$ & GL & UE & SE & BL & FL & FE & WE & Total & Gain & Net Change \\
\hline GL & 0.41 & 0.01 & 0.00 & 0.01 & 0.05 & 0.00 & 0.17 & 0.64 & 0.23 & -0.47 \\
\hline SE & 0.00 & 0.00 & 1.38 & 0.00 & 0.04 & 0.01 & 0.01 & 1.45 & 0.07 & 0.05 \\
\hline $\mathrm{BL}$ & 0.02 & 0.01 & 0.00 & 4.69 & 0.03 & 0.00 & 0.73 & 5.49 & 0.80 & -0.75 \\
\hline FL & 0.08 & 0.38 & 0.01 & 0.03 & 29.14 & 0.09 & 0.26 & 29.98 & 0.84 & -1.40 \\
\hline Total & 1.11 & 12.65 & 1.39 & 6.24 & 31.38 & 7.81 & 39.41 & 100.00 & & \\
\hline Loss & 0.70 & 0.55 & 0.02 & 1.55 & 2.24 & 0.32 & 1.94 & & & \\
\hline
\end{tabular}

In the period of 2005-2010, wetland (WE) showed the largest loss, accounting for $3.23 \%$ of the entire coastal zone, and urban (UE) showed the largest gain, $3.46 \%$ of the coastal zone (Table 5). 
Most of the lost wetland converted to urban and farmland or degraded to bare land (BL). During this time interval, the largest net loss is FL (0.91\%), and the largest net gain is urban $(1.87 \%)$. The largest contributor for the increment of urban was farmland and wetland.

Table 5. Landscape transition matrix between 2005 (columns) and 2010 (rows).

\begin{tabular}{|c|c|c|c|c|c|c|c|c|c|c|}
\hline${ }_{2010}^{2005}$ & GL & UE & SE & BL & FL & FE & WE & Total & Gain & Net Change \\
\hline GL & 0.38 & 0.02 & 0.00 & 0.01 & 0.02 & 0.00 & 0.14 & 0.58 & 0.20 & -0.43 \\
\hline SE & 0.00 & 0.07 & 1.21 & 0.00 & 0.09 & 0.07 & 0.01 & 1.45 & 0.24 & 0.01 \\
\hline BL & 0.02 & 0.01 & 0.00 & 3.52 & 0.03 & 0.02 & 1.40 & 5.01 & 1.49 & -0.39 \\
\hline FL & 0.05 & 0.97 & 0.08 & 0.06 & 27.14 & 0.40 & 0.42 & 29.12 & 1.98 & -0.91 \\
\hline Total & 0.64 & 14.74 & 1.45 & 5.40 & 30.03 & 8.03 & 39.71 & 100.00 & & \\
\hline Loss & 0.26 & 1.60 & 0.24 & 1.88 & 2.88 & 0.79 & 3.23 & & & \\
\hline
\end{tabular}

During 2010-2015, the largest loss occurred in wetland ecosystems (WE), accounting for 3.70\% of the total coastal zone, and urban (UE) showed the largest gain, 2.38\% of the total coastal zone (Table 6). Most of the lost wetland was converted to farmland or degraded to bare land. The largest net loss is wetland (1.98\%) and the largest net gain is urban $(2.06 \%)$. Wetland was the largest contributor for the increment of the urban area.

Table 6. Landscape transition matrix between 2010 (columns) and 2015 (rows).

\begin{tabular}{|c|c|c|c|c|c|c|c|c|c|c|}
\hline $2015-2010$ & GL & UE & SE & BL & FL & FE & WE & Total & Gain & Net Change \\
\hline GL & 0.52 & 0.02 & 0.00 & 0.00 & 0.00 & 0.00 & 0.28 & 0.83 & 0.31 & 0.24 \\
\hline UE & 0.04 & 16.31 & 0.04 & 0.05 & 0.81 & 0.18 & 1.25 & 18.69 & 2.38 & 2.06 \\
\hline SE & 0.00 & 0.01 & 1.39 & 0.00 & 0.01 & 0.01 & 0.00 & 1.41 & 0.02 & -0.04 \\
\hline $\mathrm{BL}$ & 0.01 & 0.01 & 0.00 & 3.66 & 0.01 & 0.01 & 0.65 & 4.36 & 0.70 & -0.70 \\
\hline FL & 0.00 & 0.15 & 0.01 & 0.02 & 27.86 & 0.05 & 1.51 & 29.59 & 1.74 & 0.52 \\
\hline $\mathrm{FE}$ & 0.00 & 0.04 & 0.01 & 0.00 & 0.13 & 7.80 & 0.02 & 7.99 & 0.19 & -0.09 \\
\hline WE & 0.02 & 0.09 & 0.00 & 1.32 & 0.26 & 0.03 & 35.42 & 37.14 & 1.72 & -1.98 \\
\hline Total & 0.59 & 16.63 & 1.45 & 5.05 & 29.07 & 8.08 & 39.12 & 100.00 & & \\
\hline Loss & 0.07 & 0.32 & 0.07 & 1.39 & 1.22 & 0.27 & 3.70 & & & \\
\hline
\end{tabular}

\subsection{Quantification of Landscape Metrics}

The quantification of landscape pattern through landscape metrics is an effective way to analyze landscape pattern changes [33,37]. Table 7 compares changes in the landscape metrics at the class level in 2000,2005, 2010 and 2015. Grasslands were the only decreasing landscape patch type: NP decreased from 606 in 2000 to 494 in 2015. The wetland NP increased the most, from 2070 in 2000 to 3053 in 2015, while MPS decreased from $282.35 \mathrm{~km}^{2}$ to $180.33 \mathrm{~km}^{2}$, which indicated that the wetland ecosystem had become more fragmented. The NP and MPS of forest, shrub, farmland, and bare land ecosystems had the same changing trend as the wetlands. Therefore, the fragmentation of these ecosystems increased. Both urban NP and MPS exhibited an increasing trend. The LPI for the wetland was the largest in 2000, 2005, 2010 and 2015, indicating that the wetland ecosystem was the dominant landscape type in the Bohai coastal zone. The results revealed that spatial patterns have changed significantly; the change direction of these ecosystems has been toward increased heterogeneity and fragmentation. 
Table 7. Landscape pattern metrics of ecosystems at the class level.

\begin{tabular}{ccccccccc}
\hline \multicolumn{2}{c}{ Metrics at Class Level } & Wetland & Farmland & Urban & Forest & Bare Land & Shrub & Grassland \\
\hline \multirow{4}{*}{ NP } & 2000 & 2070 & 2230 & 5974 & 2016 & 750 & 1017 & 606 \\
& 2005 & 2267 & 2478 & 6019 & 1002 & 2198 & 702 & 536 \\
& 2010 & 2676 & 2760 & 6436 & 2457 & 788 & 1058 & 461 \\
& 2015 & 3053 & 3028 & 6619 & 2534 & 919 & 1085 & 494 \\
\hline \multirow{3}{*}{ PD } & 2000 & 0.14 & 0.15 & 0.40 & 0.14 & 0.05 & 0.07 & 0.04 \\
& 2005 & 0.15 & 0.17 & 0.41 & 0.07 & 0.15 & 0.05 & 0.04 \\
& 2010 & 0.18 & 0.19 & 0.43 & 0.17 & 0.05 & 0.07 & 0.03 \\
& 2015 & 0.21 & 0.20 & 0.45 & 0.17 & 0.06 & 0.07 & 0.03 \\
\hline \multirow{4}{*}{ MPS } & 2000 & 282.35 & 208.56 & 31.43 & 57.48 & 123.43 & 20.32 & 27.26 \\
& 2005 & 259.55 & 179.29 & 36.34 & 21.43 & 54.14 & 116.01 & 17.80 \\
& 2010 & 216.74 & 156.14 & 38.31 & 48.73 & 95.11 & 20.37 & 19.13 \\
& 2015 & 180.33 & 144.87 & 41.87 & 46.72 & 70.31 & 19.25 & 24.92 \\
\hline \multirow{3}{*}{ LPI } & 2000 & 18.86 & 6.06 & 2.33 & 1.52 & 0.93 & 0.16 & 0.24 \\
& 2005 & 14.13 & 4.01 & 2.61 & 0.16 & 1.49 & 1.26 & 0.07 \\
& 2010 & 13.84 & 2.85 & 2.38 & 1.50 & 1.56 & 0.16 & 0.07 \\
& 2015 & 10.24 & 2.64 & 2.63 & 1.49 & 1.55 & 0.16 & 0.08 \\
\hline
\end{tabular}

NP: number of patches; PD: patch density; MPS: mean patch size; LPI: largest patch index.

A comparison of the landscape indices at the landscape level is listed in Table 8. NP increased from 14,663 in 2000 to 17,732 in 2015, while MPS steadily decreased to $83.61 \mathrm{~km}^{2}$ from $101.14 \mathrm{~km}^{2}$, indicating that some original patches were divided, and landscape heterogeneity and fragmentation were rising. SHDI has not changed much.

Table 8. Landscape pattern metrics of ecosystems at the landscape level.

\begin{tabular}{cccccc}
\hline Landscape Level & NP & PD & MPS & LPI & SHDI \\
\hline 2000 & 14,663 & 0.99 & 101.14 & 18.86 & 1.47 \\
2005 & 15,202 & 1.03 & 97.54 & 14.13 & 1.47 \\
2010 & 16,636 & 1.12 & 89.12 & 13.84 & 1.47 \\
2015 & 17,732 & 1.20 & 83.61 & 10.24 & 1.48 \\
\hline
\end{tabular}

NP: number of patches; PD: patch density; MPS: mean patch size; LPI: largest patch index; SHDI: Shannon-Weaver diversity index.

\subsection{Driving Forces}

Preliminary DCA estimated a gradient length of 0.67 SD, and thus, the use of RDA as a linear method of canonical ordination was appropriate. The results of RDA were shown in a bi-plot (Figure 5). The full RDA model using seven environmental variables explained $80.3 \%$ of the total variance within the ecosystem landscape changes (Table 9). RDA results indicated varying correlations between each ecosystem type and environmental variable. AQ and Pop were the main factors related to the change of the wetland ecosystem. Pop and GDPpc were closely related to the change of the urban ecosystem. ATm, CA, and GY had positive correlations with the change of the farmland ecosystem. 


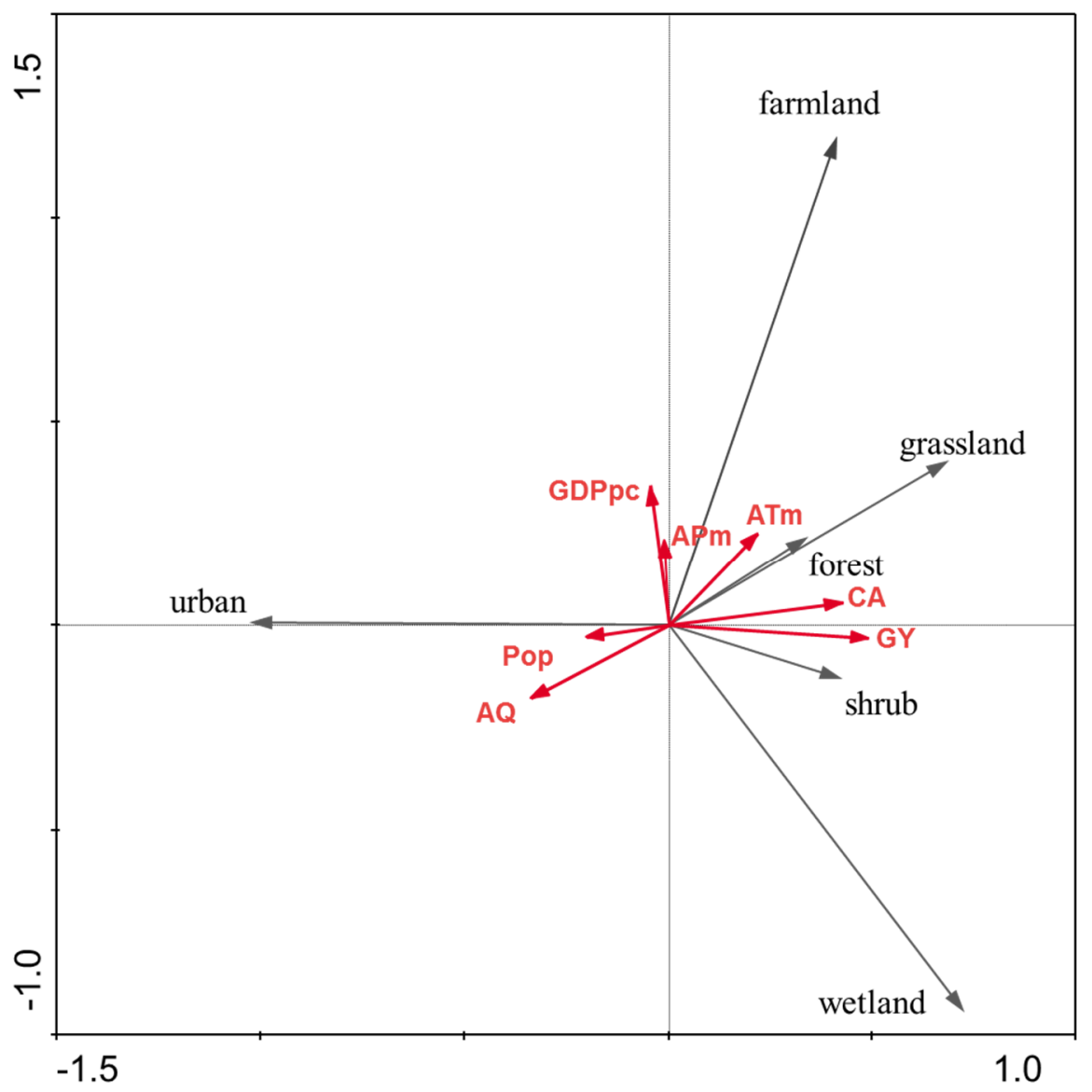

Figure 5. Redundancy analysis (RDA) of ecosystem landscape changes in relation to combined socio-economic and environmental variables from 2000 to 2015.

Table 9. Summary statistics for first four axes of RDA with the landscape changes and environmental variables for ecosystems in the Bohai coastal zone.

\begin{tabular}{cccccc}
\hline Axes & Axis 1 & Axis 2 & Axis 3 & Axis 4 & Total Variance \\
\hline Eigenvalues & 0.384 & 0.227 & 0.078 & 0.071 & 1.000 \\
Species-environment correlations & 0.984 & 0.946 & 0.880 & 0.714 & \\
CV of species data & 38.4 & 61.1 & 68.9 & 76.0 & \\
CV of species-environment relation & 47.8 & 76.1 & 85.8 & 98.0 & 1.000 \\
Sum of all eigenvalues & & & & & 0.803 \\
Sum of all canonical eigenvalues & & & & &
\end{tabular}

CV: cumulative percentage variance.

\section{Discussion}

\subsection{Land Reclamation in Bohai Coastal Zone}

Bohai coastal areas are one of the most densely populated regions in China because of their prominent biological productivity and high accessibility. Spurred by a fast-growing economy and large population, coastal administrations have aggressively expanded seafaring facilities and constructed coastal industries to promote urbanization, which has resulted in a great demand for land area [38]. As a feasible land solution for coastal development, land reclamation can alleviate the pressure of land shortages. The Changlu sea salt pan, one of China's four salt fields, is located along northern Bohai Bay. Driven by huge profit, the total area of the Changlu sea salt pan has been expanded from $216 \mathrm{~km}^{2}$ to $6580 \mathrm{~km}^{2}$ from 1949 to 1965 [38]. In the 21st century, the Bohai coastal region has become a focus of economic development with the promotion of national policies in the Bohai 
Economic Rim. Since 2000, some of the reclaimed areas have been used for mariculture and agriculture, but most of them are used to accommodate the demand for transport, employment and other urban facilities. The Tangshan Caofeidian Industrial Zone and Tianjin Binhai New area are typical examples of coastal reclamation projects. Caofeidian Industrial District is located in the heartland of Bohai Bay. The reclamation plan was carried out in 2004 and is set to be finished in 2020 . About $310 \mathrm{~km}^{2}$ waterfront area was reclaimed for deep water port and for steel, chemical, electric works, and nuclear power industries [38]. Tianjin New District is another example, nearly $2270 \mathrm{~km}^{2}$ of reclaimed area was used for the construction of new housing, ports and other coastal industries [39]. Furthermore, some coastal provinces and metropolises have developed their own coastal economy development plans to boost the marine economy. For instance, in Shandong province, the "Special Plan on Focused and Intensive Sea Use for Blue Economic Zone Construction around Shandong Peninsula (2009-2020)" proposed implementing focused and intensive use of the sea by setting up a total of nine big and 10 small costal industrial complexes, covering a total area of $1500 \mathrm{~km}^{2}$, including $520 \mathrm{~km}^{2}$ from reclamation [40]. Reclamation has greatly altered the spatial distribution of ecosystems of the Bohai coastal zone, wetlands have been transformed into farmland and urban or degraded land into bare land. Over the last 20 years, insufficient ecological considerations and inadequate coastal protection measures have resulted in sharp area reduction and ecosystem service declines of wetland ecosystems. Presently, the Chinese government has recognized the conflicts between wetland ecosystem protection and the space demands from a fast-growing economy. The Chinese government has committed to following the concept of sustainable development via policy, legislation, science, and management approaches, by strengthening laws and regulations and improving coastal spatial planning so that ecological protection can be properly taken into management consideration [38]. These efforts lay a good foundation for coastal restoration and scientific decision-making or management of coastal conservation.

\subsection{Landscape Changes and Their Impact on Coastal Habitat}

The above results indicated that the coastal landscape pattern in Bohai has changed dramatically over the past 15 years. The natural wetland consistently decreased from 2000 to 2015 and became fragmentated and heterogenous, with a significant decrease in marshland and lake areas. Thus, the habitat gradually shrunk and diminished. Waterbirds are crucial indicators for assessment of ecosystem health $[41,42]$. The species and number of waterbirds can reflect the health status of wetland ecosystem. Extensive mudflats of northern Bohai Bay have formerly supported over 65,000 Red Knots, $60 \%$ of the entire flyway population, and 80,000 Curlew Sandpipers ( $45 \%$ of the population) on their northward migration [43]. However, in recent years, approximately $450 \mathrm{~km}^{2}$ of offshore area, including $218 \mathrm{~km}^{2}$ of intertidal flats have been reclaimed for the Caofeidian Industrial District and Tianjin Industrial District, which resulted in increasing loss and degradation of waterbird habitat. Only a small stretch of mudflats remains in this area, forcing the northward migrating birds to concentrate and crowd into the small remaining area [44]. It was reported that the spring peak numbers of Curlew Sandpiper C. ferruginea increased from 3\% in 2007 to $23 \%$ in 2010 of the flyway population [44]. Fragmentation and loss of waterbird habitat leads to a decline in waterbird numbers $[45,46]$ or to the movement of birds to nearby suitable habitats [47]; the latter can lead to increased densities at other sites and consequently an increase in mortality of the displaced birds, leading to an overall loss of birds [48]. Landscape modification and habitat fragmentation have negative impacts on coastal ecosystems and biodiversity because Bohai Bay is a crucial area for waterbirds to make stopovers or winter here. It is important that decision makers and the public are made fully aware of the great importance of Bohai Bay for waterbirds and of the potential environmental disasters for all those that rely on the tidal flats as a food source [49].

\subsection{Limitatios of Driving Forces Analysis}

By selecting two natural and five socio-economic factors, we examined the relationship between landscape changes and driving forces. However, the study area in this research is a buffer zone, it is 
very difficult to gain corresponding relative socio-economic data. We used socio-economic data of coastal cities to conduct the analysis of driving forces. A bivariate correlation method was employed to testify to the feasibility of driving forces in the case of inconsistent analysis units. We used spatial distribution data on population (POPs) and GDP (GDPs) and calculated mean values of POPs and GDPs with ArcGIS 10.3, named POPsm and GDPsm. Then the relationships between POPsm and Pop, GDPsm and GDP were analyzed in SPSS 19.0 (IBM, Armonk NY, USA). The results indicated that Pop showed significant correlation with POPsm, and GDP showed extremely significant correlation with GDPsm (Table 10). The results of correlation analysis indicated that socio-economic data of coastal cities can be used to conduct the analysis of driving forces.

Table 10. The relationship analysis between Pop and POPsm as well as GDP and GDPsm.

\begin{tabular}{|c|c|c|c|c|c|}
\hline & Items & Pop & & Items & GDP \\
\hline POPsm & $\begin{array}{c}\text { Pearson correlation } \\
p \text { value }\end{array}$ & $\begin{array}{c}0.627^{*} \\
0.022\end{array}$ & GDPsm & $\begin{array}{c}\text { Pearson correlation } \\
\quad p \text { value }\end{array}$ & $\begin{array}{l}0.886^{* *} \\
<0.01\end{array}$ \\
\hline
\end{tabular}

In addition, Due to unavailable data, unknown influencing factors and factors that are impossible to quantify, it is impossible to include all socio-economic and environmental variables that influence landscape changes [50]. Natural factors, such as elevation, slope direction and altitude are influential in reshaping landscapes. Whereas further elaborate analysis wasn't performed due to data limitation. In this study, we merely analyzed and displayed the consequences of landscape spatial changes and paid less attention to the landscape process and function. The difference between correlation and causality should be distinguished in future researches of landscape changes.

The correlation analysis is helpful for the identification of influential factors, the magnitude of factors is not quantified yet. Focusing on the changes in landscape processes and functions is helpful for the identification of dominant factors, and then it is possible to further explore the driving mechanism of landscape changes.

\section{Conclusions}

The ecosystem landscape pattern in the Bohai coastal zone has changed significantly over the 15 years of this research. The wetland ecosystem maintained the largest area, followed by the farmland and urban ecosystems. The main trend of landscape changes was characterized by the expansion of the urban area and the shrinkage of farmland, wetland and bare land.

There was no obvious changing trend in dynamic degree $(K)$. The analysis of dynamic degree showed that the extent of grassland change was the largest from 2000-2005 and 2010-2015, accounting for $-8.46 \%$ and $7.93 \%$ of the change in landscape, respectively. The $K$ value of urban was the highest from $2005-2010$, accounting for $2.56 \%$ of the change in total landscape. The landscape change index level (LCI) in the period 2000-2005 and 2010-2015 was relatively higher than the index for the period 2005-2010, indicating that the largest changes of the landscape occurred in the first and the third time interval.

The transformation of landscape types mainly occurred in wetland, farmland, urban and bare land ecosystems. The farmland showed the largest loss and urban showed the largest gain during 2000-2005, and farmland was the main contributor for the increment of urban. During 2005-2010 and 2010-2015, the wetland showed the largest loss and urban still showed the largest gain; most of the wetland converted to farmland and urban or degraded to bare land; wetland and farmland were the main contributors for the expansion of urban.

The overall NP increased, whereas MPS decreased, indicating that the spatial landscape pattern had become fragmented and heterogeneous. 
The results of the RDA model show that landscape changes are indicated by socio-economic and natural variables. Human activity is a major driving force in shaping the spatial distribution of the ecosystems.

Author Contributions: M.C. and Z.O. conceived, designed and performed the research. L.K. and Z.O. contributed to the interpretation of the data for the study; M.C. and B.H. analyzed the data and M.C. and Z.O. wrote the paper and approved the final vision to be published.

Funding: This study was supported by the Special Fund of Forestry Industrial Research for Public Welfare of China (201404305).

Acknowledgments: We are grateful to Ecosystem Assessment and Eco-security Database for land use data. We thank schoolmates and International Science Editing (http://www.internationalscienceediting.com) who provided helpful suggestions on the manuscript improvement, in particular Yan Zhang, Lingqiao Kong, Binbin Huang, Ruida Li.

Conflicts of Interest: The authors declare no conflict of interest.

\section{References}

1. Ke, C.; Zhang, D.; Wang, F.; Chen, S.; Schmullius, C.; Boerner, W.; Wang, H. Analyzing coastal wetland change in the Yancheng National Nature Reserve, China. Reg. Environ. Chang. 2011, 11, 161-173. [CrossRef]

2. Shi, L.; Liu, F.; Zhang, Z.; Zhao, X.; Liu, B.; Xu, J.; Wen, Q.; Yi, L.; Hu, S. Spatial differences of coastal urban expansion in China from 1970s to 2013. Chin. Geogr. Sci. 2015, 25, 389-403. [CrossRef]

3. Martínez, M.L.; Intralawan, A.; Vázquez, G.; Pérez-Maqueo, O.; Sutton, P.; Landgrave, R. The coasts of our world: Ecological, economic and social importance. Ecol. Econ. 2007, 63, 254-272. [CrossRef]

4. Barbier, E.B.; Koch, E.W.; Silliman, B.R.; Hacker, S.D.; Wolanski, E.; Primavera, J.; Granek, E.F.; Polasky, S.; Aswani, S.; Cramer, L.A.; et al. Coastal ecosystem-based management with nonlinear ecological functions and values. Science 2008, 319, 321-323. [CrossRef] [PubMed]

5. Cao, W.; Wong, M.H. Current status of coastal zone issues and management in China: A review. Environ. Int. 2007, 33, 985-992. [CrossRef] [PubMed]

6. Wang, Y. Coastal Management in China. Ocean Management in Global Change. In Proceedings of the Conference on Ocean Management in Global Change, Genoa, Italy, $22-26$ June 1992; CRC Press: London, UK, 2003; p. 469.

7. Song, W.; Deng, X.; Yuan, Y.; Wang, Z.; Li, Z. Impacts of land-use change on valued ecosystem service in rapidly urbanized North China Plain. Ecol. Model 2015, 318, 245-253. [CrossRef]

8. Nahuelhual, L.; Carmona, A.; Aguayo, M.; Echeverria, C. Land use change and ecosystem services provision: A case study of recreation and ecotourism opportunities in Southern Chile. Landsc. Ecol. 2014, 29, 329-344. [CrossRef]

9. Mendoza-González, G.; Martínez, M.L.; Lithgow, D.; Pérez-Maqueo, O.; Simonin, P. Land use change and its effects on the value of ecosystem services along the coast of the Gulf of Mexico. Ecol. Econ. 2012, 82, 23-32. [CrossRef]

10. Zang, S.; Wu, C.; Liu, H.; Na, X. Impact of urbanization on natural ecosystem service values: A comparative study. Environ. Monit. Assess. 2011, 179, 575-588. [CrossRef] [PubMed]

11. Napton, D.E.; Auch, R.F.; Headley, R.; Taylor, J.L. Land changes and their driving forces in the Southeastern United States. Reg. Environ. Chang. 2010, 10, 37-53. [CrossRef]

12. Lichtenberg, E.; Ding, C. Assessing farmland protection policy in China. Land Use Policy 2008, 25, 59-68. [CrossRef]

13. Bender, O.; Boehmer, H.J.; Jens, D.; Schumacher, K.P. Analysis of land-use change in a sector of Upper Franconia (Bavaria, Germany) since 1850 using land register records. Landsc. Ecol. 2005, 20, 149-163. [CrossRef]

14. Braimoh, A.K. Random and systematic land-cover transitions in Northern Ghana. Agric. Ecosyst. Environ. 2006, 113, 254-263. [CrossRef]

15. Xiaofeng, D.; Lichen, L.; Jianhua, W.; Jin, S.; Jinghu, P. Analysis of the landscape change at River Basin scale based on SPOT and TM fusion remote sensing images: A case study of the Weigou River Basin on the Chinese Loess Plateau. Int. J. Earth Sci. 2009, 98, 651-664. [CrossRef] 
16. Maleki Najafabadi, S.; Soffianian, A.; Rahdari, V.; Amiri, F.; Pradhan, B.; Tabatabaei, T. Geospatial modeling to identify the effects of anthropogenic processes on landscape pattern change and biodiversity. Arab J. Geosci. 2015, 8, 1557-1569. [CrossRef]

17. Fan, Q.; Ding, S. Landscape pattern changes at a county scale: A case study in Fengqiu, Henan Province, China from 1990 to 2013. Catena 2016, 137, 152-160. [CrossRef]

18. Zhao, R.; Chen, Y.; Shi, P.; Zhang, L.; Pan, J.; Zhao, H. Land use and land cover change and driving mechanism in the arid inland river basin: A case study of Tarim River, Xinjiang, China. Environ. Earth Sci. 2013, 68, 591-604. [CrossRef]

19. Zhu, Z.; Liu, L.; Chen, Z.; Zhang, J.; Verburg, P.H. Land-use change simulation and assessment of driving factors in the loess hilly region-A case study as Pengyang County. Environ. Monit. Assess. 2010, 164, 133-142. [CrossRef]

20. Fathizad, H.; Rostami, N.; Faramarzi, M. Detection and prediction of land cover changes using Markov chain model in semi-arid rangeland in Western Iran. Environ. Monit. Assess. 2015, 187, 629. [CrossRef]

21. Ramankutty, N.; Foley, J.A. Estimating historical changes in global land cover: Croplands from 1700 to 1992. Glob. Biogeochem. Cycles 1999, 13, 997-1027. [CrossRef]

22. Plieninger, T.; Draux, H.; Fagerholm, N.; Fagerholm, N.; Bieling, C.; Bürgi, M.; Kizos, T.; Kuemmerle, T.; Primdahl, J. The driving forces of landscape change in Europe: A systematic review of the evidence. Land Use Policy 2016, 57, 204-214. [CrossRef]

23. Klijn, J.A. Driving Forces behind Landscape Transformation in Europe, From a Conceptual Approach to Policy Options. In The New Dimensions of the European Landscapes; Jongman, R.G.H., Ed.; The New Dimensions of the European Landscapes: Wageningen, The Netherlands, 2004; pp. 201-218.

24. Burgi, M.; Hersperger, A.M.; Schneeberger, N. Driving forces of landscape change-Current and new directions. Landsc. Ecol. 2004, 19, 857-868. [CrossRef]

25. Gao, P.; Niu, X.; Wang, B.; Zheng, Y. Land use changes and its driving forces in hilly ecological restoration area based on GIS and RS of Northern China. Sci. Rep. 2015, 5, 11038. [CrossRef] [PubMed]

26. Krajewski, P.; Solecka, I.; Mrozik, K. Forest Landscape Change and Preliminary Study on Its Driving Forces in Ślęża Landscape Park (Southwestern Poland) in 1883-2013. Sustainability 2018, 10, 4526. [CrossRef]

27. Finkl, C.W. Coastal Classification: Systematic Approaches to Consider in the Development of a Comprehensive Scheme. J. Coast. Res. 2004, 20, 166-213. [CrossRef]

28. Ouyang, Z.; Zheng, H.; Xiao, Y.; Polasky, S.; Liu, J.; Xu, W.; Wang, Q.; Zhang, L.; Xiao, Y.; Rao, E.; et al. Improvements in ecosystem services from investments in natural capital. Science 2016, 352, 1455-1459. [CrossRef]

29. Puyravaud, J. Standardizing the calculation of the annual rate of deforestation. Forest Ecol. Manag. 2003, 177, 593-596. [CrossRef]

30. Krajewski, P.; Solecka, I.; Barbara-Mastalska-Cetera. Landscape Change Index as a Tool for Spatial Analysis. IOP Conf. Ser. Mater. Sci. Eng. 2017, 245, 72014. [CrossRef]

31. Pontius, R.G.; Shusas, E.; Mceachern, M. Detecting important categorical land changes while accounting for persistence. Agric. Ecosyst. Environ. 2004, 101, 251-268. [CrossRef]

32. Seto, K.C.; Fragkias, M. Quantifying Spatiotemporal Patterns of Urban Land-use Change in Four Cities of China with Time Series Landscape Metrics. Landsc. Ecol. 2005, 20, 871-888. [CrossRef]

33. Forman, R.T.T.; Godron, M. Landscape Ecology; Wiley: New York, NY, USA, 1986.

34. Su, S.; Xiao, R.; Jiang, Z.; Zhang, Y. Characterizing landscape pattern and ecosystem service value changes for urbanization impacts at an eco-regional scale. Appl. Geogr. 2012, 34, 295-305.

35. Mcgarigal, K.M.B. FRAGSTATS: Spatial Patterm Analysis Program for Quantifying Landscape Structure. Available online: https:/ / www.fs.usda.gov/treesearch/pubs/3064 (accessed on 17 December 2018).

36. Zhang, Z.; van Coillie, F.; Ou, X.; de Wulf, R. Integration of Satellite Imagery, Topography and Human Disturbance Factors Based on Canonical Correspondence Analysis Ordination for Mountain Vegetation Mapping: A Case Study in Yunnan, China. Remote Sens. 2014, 6, 1026-1056. [CrossRef]

37. Turner, M.G.; Gardner, R.H.; O’Neill, R.V. Landscape Ecology in Theory and Practice: Pattern and Process; Springer: New York, NY, USA, 2001.

38. Wang, W.; Liu, H.; Li, Y.; Su, J. Development and management of land reclamation in China. Ocean Coast. Manag. 2014, 102, 415-425. [CrossRef] 
39. Xiao, Q.; Wang, Y.; Yu, M.; Yu, D.; Zheng, X.; Zhou, B.; Wei, Y.; Zhong, J.; Yang, Y.; Zeng, F.; et al. Driving factors of coastal wetland degradation in Binhai New Area of Tianjin. Acta. Sci. Circumst. 2012, 32, 480-488.

40. Blue Economic Zone (BEZ) Executive Summary: Shandong Peninsula Blue Economic Zone, Shandong, China. Available online: https:/ / www.unsw.adfa.edu.au/sino-australian-research-centre-for-coastal-management/ blue-economic-zone-bez-executive-summary-shandong-peninsula-blue-economic-zone-shandong-china (accessed on 11 May 2015).

41. Ogden, J.C.; Baldwin, J.D.; Bass, O.L.; Browder, J.A.; Cook, M.I.; Frederick, P.C.; Frezza, P.E.; Galvez, R.A.; Hodgson, A.B.; Meyer, K.D.; et al. Waterbirds as indicators of ecosystem health in the coastal marine habitats of southern Florida: 1. Selection and justification for a suite of indicator species. Ecol. Indic. 2014, 44, 148-163. [CrossRef]

42. Robledano, F.; Esteve, M.A.; Farinós, P.; Carreno, M.F. Terrestrial birds as indicators of agricultural-induced changes and associated loss in conservation value of Mediterranean wetlands. Ecol. Indic. 2010, 10, 274-286. [CrossRef]

43. China's Land Reclamation is Endangering Some of the World's Rarest Water Birds. Available online: https: / / www.citymetric.com/horizons/chinas-land-reclamation-endangering-some-worlds-rarestwater-birds-1453 (accessed on 2 October 2015).

44. Yang, H.-Y.; Chen, B.; Barter, M.; Piersma, T.; Zhou, C.-F.; Li, F.-S.; Zhang, Z.-W. Impacts of tidal land reclamation in Bohai Bay, China: Ongoing losses of critical Yellow Sea waterbird staging and wintering sites. Bird Conserv. Int. 2011, 21, 241-259. [CrossRef]

45. Kraan, C.; van Gils, J.A.; Spaans, B.; Dekinga, A.; Bijleveld, A.I.; van Roomen, M.; Kleefstra, R.; Piersma, T. Landscape-scale experiment demonstrates that Wadden Sea intertidal flats are used to capacity by molluscivore migrant shorebirds. J. Anim. Ecol. 2009, 78, 1259-1268. [CrossRef]

46. Moores, N.; Rogers, D.I.; Rogers, K.; Hansbro, P.M. Reclamation of tidal flats and shorebird declines in Saemangeum and elsewhere in the Republic of Korea. Emu. Austral. Ornithol. 2016, 116, 136-146. [CrossRef]

47. Burton, N.H.K.; Rehfisch, M.M.; Clark, N.A.; Dodd, S.G. Impacts of sudden winter habitat loss on the body condition and survival of redshank Tringa totanus. J. Appl. Ecol. 2006, 43, 464-473. [CrossRef]

48. Goss-Custard, J.D.; Burton, N.H.K.; Clark, N.A.; Ferns, P.N.; McGrorty, S.; Reading, C.J.; Rehfisch, M.M.; Stillman, R.A.; Townend, I.; West, A.D.; et al. Test of a behavior-based individual-based model: Response of shorebird mortality to habitat loss. Ecol. Appl. 2006, 16, 2215-2222. [CrossRef]

49. Sato, S. Drastic change of bivalves and gastropods caused by the huge reclamation projects in Japan and Korea. Plankton Benthos Res. 2006, 1, 123-137. [CrossRef]

50. Marcucci, D.J. Landscape history as a planning tool. Landsc. Urban Plan 2000, 49, 67-81. [CrossRef] 